\title{
ANTIMICROBIAL AND ANTIOXIDANT ACTIVITIES OF A MALAYSIAN MEDICINAL PLANT ANISOPHYLLEA DISTICHA (JACK) BAILL. AND QUANTIFICATION OF ITS PHENOLIC CONSTITUENTS
}

\author{
Nurul Ashikin Abdul Bari, Sahena Ferdosh* and Md Zaidul Islam Sarker ${ }^{1}$ \\ Department of Plant Science, Faculty of Science, International Islamic University \\ Malaysia (IIUM), Kuantan, Pahang, Malaysia
}

Keywords: Anisophyllea disticha, Total phenolic content, Antimicrobial activity, Antioxidant activity

\begin{abstract}
The ethanolic extracts of different parts of Anisophyllea disticha were tested for antimicrobial capability using disc diffusion assay. The result revealed positive growth inhibitory activity, but was considered weak for all extracts against Gram positive bacteria. Leaf extract displayed the highest zone of inhibition with values of $10.67 \pm 0.58$ and $8.67 \pm 0.58 \mathrm{~mm}$ against Staphylococcus epidermidis and S. aureus, respectively. On the other hand, stem showed the highest amount of total phenolic content (TPC) $(27.73 \pm 4.10 \mathrm{mg}$ GAE/g extract) and similar trend was also observed in antioxidant potential in terms of DPPH radical scavenging activity $(66.20 \pm 11.74 \%)$ and ferric reducing antioxidant power assay (FRAP) $(203.63 \pm 16.03 \mathrm{mg} \mathrm{Fe}(\mathrm{II}) / \mathrm{g}$ extract). High positive correlation was found between TPC and antioxidant activities, suggesting that phenolic compounds contribute to the antioxidant power of plant extracts. HPLC analysis identified and quantified gallic acid, $p$-coumaric, ferulic acid and quercetin in the extracts.
\end{abstract}

\section{Introduction}

Anisophyllea disticha locally known as Raja berangkat, is a tropical shrub that grows normally in primary or old secondary lowlands as well as hill forests in Malaysia, Indonesia, Singapore, Brunei and Philippines (Singh 2016). This plant belonging to Anisophylleaceae is offering various benefits especially in primary health care. Local people utilize its leaves and stem in curing diarrhea, dysentery and fever either by eating raw or soaking in liquid to prepare the infusion. Patients with jaundice make use of decoction of leaves of A. disticha by routinely bathing to cure the disease. Accoding to Quattrocchi (2012) crushed young leaves of A. disticha which are able to heal cuts and wounds while its fresh fruits are eaten for septic stings by bees and hornets. Ong (2004) stated that drinking the decoction of roots in combination with onion and black cumin (Nigella sativa) are able to relieve weariness and body aches. Apart from that, the boiled roots are used to revitalize the birth canal during post parturition, treat infertility in women and refresh men's body (Ong 2004, Suharjito et al. 2014). Furthermore, the root of A. disticha is used as tonic to keep person healthy and acts as anti-aging (Chian 2019).

Native people have been using herbal products in treating diarrhea, fever, redness and swelling since ancient times, whereby in modern clinical practice, these symptoms can be associated with bacteria causing diseases (Keller and Nugraha 2011). Numerous therapeutically active plant-derived constituents were discovered from the research of traditional cures and folk knowledge of plants. The previous research findings have shown the antimicrobial potential of different parts of A. laurina against bacterial strains and fungi using agar well diffusion and microdilution methods (Onivogui et al. 2016).

*Author for correspondence: <sahena@iium.edu.my>. Faculty of Pharmacy, IIUM, Kuantan, Pahang, Malaysia. 
So far few pharmacological investigations on $A$. disticha have been carried out despite its high utilization by the folklore. Therefore, the present study aimed to evaluate the antimicrobial activity, total phenolic content (TPC), the antioxidant activities of different parts of $A$. disticha in terms of DPPH radical scavenging activities and ferric reducing antioxidant power assay (FRAP) and to analyse its polyphenols by high performance liquid chromatography (HPLC).

\section{Materials and Methods}

A. disticha collected from Kenyir Lake, Terengganu, Malaysia was authenticated and a voucher specimen (PIIUM 0003-2) has been deposited at Kulliyyah of Pharmacy, International Islamic University Malaysia. Different parts of A. disticha, namely leaf, stem and root were washed with clean water followed by drying in oven at $40^{\circ} \mathrm{C}$ for a week. The dried samples were ground to fine powder by electric grinder and extracted in Soxhlet (Gerhardt, Germany) apparatus using $250 \mathrm{ml}$ ethanol in dark for $12 \mathrm{hrs}$. The extracts were then evaporated to dryness by rotary evaporator at $60^{\circ} \mathrm{C}$.

The antimicrobial activity of leaf, stem and root extracts of $A$. disticha was determined against Gram positive bacteria S. epidermidis (ATCC 12228) and S. aureus (ATCC 25923) and Gram negative bacteria Enterobacter aerogenes (ATCC 13048) and Escherichia coli (ATCC 25922). Antimicrobial activity of extracts was evaluated by using disc diffusion assay following the method by Bauer et al. (1966).

Total phenolic content was analysed using the Folin-Ciocalteu assay following the method of Zheng and Wang (2001), with some alterations. For this, $58 \mu \mathrm{l}$ of diluted extracts $(1-5 \mathrm{mg} / \mathrm{ml})$ were oxidized with $968 \mu \mathrm{l}$ Folin-Ciocalteu reagent (diluted $1: 10)$ and the reaction solution was neutralized with $774 \mu \mathrm{l}$ of $5 \%$ sodium carbonate $\left(\mathrm{Na}_{2} \mathrm{CO}_{3}\right)$ solution. The absorbance was measured at $760 \mathrm{~nm}$ with a microplate reader spectrophotometer (Infinite M200 Pro) after incubation for $60 \mathrm{~min}$ in dark condition. Gallic acid was used as the standard to prepare the calibration curve $\left(y=4.5222 \mathrm{x}, \mathrm{R}^{2}=0.9987\right)$ in the linear range of $0.02-0.20 \mathrm{mg} / \mathrm{ml}$. The results are expressed as $\mathrm{mg} \mathrm{GAE/g} \mathrm{extract} \mathrm{sample.}$

The free radical scavenging activity of the extracts was evaluated by using 2,2-diphenyl-1picrylhydrazyl (DPPH) assay according to Liu et al. (2008) with some modifications. A volume of $40 \mu \mathrm{l}$ of ethanolic extracts $(0.2-1.0 \mathrm{mg} / \mathrm{ml})$ was mixed with $160 \mu \mathrm{l}$ of $0.079 \mathrm{mg} / \mathrm{ml} \mathrm{DPPH}$ in methanol. After $15 \mathrm{~min}$ of incubation in the dark at room temperature, the absorbance at $517 \mathrm{~nm}$ was measured against blank. Gallic acid was used as standard and the scavenging activity was estimated based on the percentage of DPPH radical scavenged.

The reducing power was determined according to the procedure described by Benzie and Strain (1996), with a slight adaptation for ferric reducing antioxidant power assay (FRAP). Here, $80 \mu \mathrm{l}$ of each of the appropriately diluted samples $(0.2-1.0 \mathrm{mg} / \mathrm{ml})$ along with $1 \mathrm{ml}$ of deionized water were mixed with $600 \mu \mathrm{l}$ freshly prepared FRAP reagent and the mixture was incubated at $37^{\circ} \mathrm{C}$ for $30 \mathrm{~min}$. The absorbance was measured at $539 \mathrm{~nm}$ using a microplate reader spectrophotometer (Infinite M200 Pro). FRAP working solution with deionized water instead of a sample was used as blank. The reducing power was calculated from ferrous sulfate calibration curve $\left(\mathrm{y}=3.0636 \mathrm{x}, \mathrm{R}^{2}=0.998\right)$ with linear range of $0.1-1.0 \mathrm{mg} / \mathrm{ml}$. The results have been expressed as $\mathrm{mg} \mathrm{Fe}(\mathrm{II}) / \mathrm{g}$ sample extract.

Phenolic compounds were determined by HPLC according to method described by TasioulaMargari and Tsabolatidou (2015) with slight adaptations. The mobile phase used consisted of methanol:acetonitrile (5:50) (Solvent A) and 1\% formic acid in water (45) (Solvent B). The quantification of each compound was determined according to the peak area measurements. The 
contents of constituents under study were expressed in $\mu \mathrm{g} / \mathrm{g}$ extract as a mean value \pm standard deviation of three independent analyses.

All experiments were performed in triplicate and the results have been presented as mean \pm standard deviation. Experimental data were analyzed using Excel (Microsoft Inc.) and Statistical Package for Social Science (SPSS) version 20.0 software. Analysis of variance (ANOVA) and Duncan's multiple range test were used to determine the significance of differences among the means, and $\mathrm{p}<0.05$ was considered significant.

\section{Results and Discussion}

Table 1 demonstrates the antibacterial activity of the ethanolic extracts from different parts of A. disticha. It is evident from the Table that the test samples inhibited the growth of tested bacteria with varying degree. The present study showed statistically significant difference in antibacterial activity of leaf and root extracts against $S$. epidermidis with diameter of zone of inhibition of $10.67 \pm 0.58 \mathrm{~mm}$ and $9.00 \pm 0.00 \mathrm{~mm}$, respectively, while no significant difference was observed between stem $(9.67 \pm 0.58 \mathrm{~mm})$ and leaf as well as root extracts (Table 1). Furthermore, statistically insignificant difference was recorded among inhibitory activity of leaf $(8.67 \pm 0.58$ $\mathrm{mm})$, stem $(8.33 \pm 0.58 \mathrm{~mm})$ and root $(7.67 \pm 0.58 \mathrm{~mm})$ against $S$. aureus. According to Prabuseenivasan et al. (2006), the positive result was indicated by the zone of inhibition with diameter of more than $7 \mathrm{~mm}$. The present study showed that different parts of A. disticha inhibited bacterial growth but their effectiveness is considered weak. The result of antimicrobial potential of A. disticha was in line with the previous study by Keller and Nugraha (2011) who demonstrated the sensitivity of $S$. aureus to methanolic extracts of leaf and stem of A. disticha with a rate of $25 \%$ or less than control. It was also observed that the tested plant parts failed to inhibit Gramnegative bacteria namely E. aerogenes and E. coli. As reported by Yilmaz et al. (2008), Grampositive bacteria are more vulnerable to antibiotics as they possess only outer peptidoglycan layer which does not work effectively as permeability barrier. On the other hand, the cell walls of Gramnegative bacteria are impermeable to lipophilic solutes as they comprise of an outer phospholipidic membrane bearing the structural lipopolysaccharide components (Sulaiman et al. 2011). The variations of the results could be attributed by various intrinsic and extrinsic influences such as climatic and environmental factors, strain differences, extraction procedure and the approaches used to access antimicrobial potential (Kaur and Arora 2009).

Table 1. Antibacterial activity of different parts of $A$. disticha against selected pathogens.

\begin{tabular}{lcccc}
\hline Extracts & \multicolumn{3}{c}{ Diameter of zone of inhibition $(\mathrm{mm})$} \\
\cline { 2 - 5 } & S. epidermidis & S. aureus & E. aerogenes & E. coli \\
\hline Leaf & $10.67 \pm 0.58^{\mathrm{a}}$ & $8.67 \pm 0.58^{\mathrm{a}}$ & - & - \\
Stem & $9.67 \pm 0.58^{\mathrm{ab}}$ & $8.33 \pm 0.58^{\mathrm{a}}$ & - & - \\
Root & $9.00 \pm 0.00^{\mathrm{b}}$ & $7.67 \pm 0.58^{\mathrm{a}}$ & - & - \\
Gentamycin (+) & $28.33 \pm 0.58$ & $21.67 \pm 0.58$ & $28.33 \pm 0.58$ & $21.00 \pm 0.00$ \\
Methanol (-) & - & - & - & -
\end{tabular}

The values were expressed as mean \pm standard deviation $(n=3)$. Values in the same column with different superscript letter were considered as significantly different $(\mathrm{p}<0.05)$; - no activity.

Results of the amount of total phenolic compounds present in different parts of A. disticha showed that at sample concentration of $3 \mathrm{mg} / \mathrm{ml}$, the stem extract exhibited the highest amount of phenolic compounds followed by root and leaf with mean values of $27.73 \pm 4.10 \mathrm{mg} \mathrm{GAE} / \mathrm{g}$ 
extract, $19.50 \pm 0.87 \mathrm{mg} \mathrm{GAE} / \mathrm{g}$ extract and $12.19 \pm 1.77 \mathrm{mg}$ GAE$/ \mathrm{g}$ extract, respectively (Table 2). Total phenolic contents showed significant differences $(\mathrm{p}<0.05)$ among different plant parts. Until today, no study has been reported for quantitative phenolic content of A. disticha.

Results presented in Table 2 showed that at sample concentration of $0.6 \mathrm{mg} / \mathrm{ml}$, the stem of $A$. disticha extract exhibited the highest antioxidant activity $(66.20 \pm 11.74 \%)$, followed by root $(56.66 \pm 15.00 \%)$ and leaf extract $(31.06 \pm 12.57 \%)$. The scavenging capability of stem was significantly different $(\mathrm{p}<0.05)$ compared to leaf extract while no significant differences $(\mathrm{p}>$ 0.05 ) were detected between the root and other parts of plant extract (Table 2). Siddhuraju et al. (2002) stated that the presence of high proportions of tannins (proanthocyanidins), flavonols and xanthones in stem bark fractions might contribute to high scavenging efficiency toward DPPH radicals. The antioxidant activity in terms of FRAP assay whereby at sample concentration of 0.6 $\mathrm{mg} / \mathrm{ml}$, the stem extract exhibited significant $(\mathrm{p}<0.05$ ) total mean value of $203.63 \pm 16.03 \mathrm{mg}$ $\mathrm{Fe}$ (II)/g extracts compared to leaf $(87.15 \pm 22.29 \mathrm{mg} \mathrm{Fe}(\mathrm{II}) / \mathrm{g}$ extracts) whereas there were no significant differences ( $\mathrm{p}>0.05)$ between the stem and root $(200.06 \pm 44.56 \mathrm{mg} \mathrm{Fe}(\mathrm{II}) / \mathrm{g}$ extracts). The order of plant parts in terms of ferric reducing activity is consistent with that of TPC and DPPH free radical scavenging activity. On the whole, the stem bark extract exhibited a much greater antioxidant activities and phenolic content compared to leaf and root. These results are in agreement with the previous findings reported by Onivogui et al. (2017) who reported that the reducing power of ethanolic stem extract of A. laurina was higher compared to leaf extract with a value of $36060.9 \mu \mathrm{mol} \mathrm{TE} / 100 \mathrm{~g}$ extract.

Table 2. Total phenolic content and antioxidant activities of $\boldsymbol{A}$. disticha.

\begin{tabular}{|c|c|c|c|}
\hline \multirow[t]{2}{*}{ Sample } & \multirow{2}{*}{$\begin{array}{l}\text { Total phenolic content } \\
\text { (mg GAE/g extract) }\end{array}$} & \multicolumn{2}{|c|}{ Antioxidant activities } \\
\hline & & $\begin{array}{l}\text { Scavenging activity } \\
\text { (\% inhibition })\end{array}$ & $\begin{array}{c}\text { Reducing power } \\
\text { (mg Fe(II)/g extract) }\end{array}$ \\
\hline Leaf & $12.19 \pm 1.77^{\mathrm{a}}$ & $31.06 \pm 12.57^{\mathrm{a}}$ & $87.15 \pm 22.29^{\mathrm{a}}$ \\
\hline Stem & $27.73 \pm 4.10^{\mathrm{c}}$ & $66.20 \pm 11.74^{b}$ & $203.63 \pm 16.03^{b}$ \\
\hline Root & $19.50 \pm 0.87^{\mathrm{b}}$ & $56.66 \pm 15.00^{\mathrm{ab}}$ & $200.06 \pm 44.56^{\mathrm{b}}$ \\
\hline
\end{tabular}

The values were expressed as mean \pm standard deviation $(n=3)$. Values in the same column with different superscript letter were considered as significantly different $(\mathrm{p}<0.05)$.

Positive and significant correlations were found between TPC and DPPH free radical scavenging activity $(r=0.815)$ and FRAP assay $(r=0.800)$. The findings support the hypothesis that phenolic compounds, on the basis of the Folin-Ciocalteu assay, contribute to the total antioxidant capacity of plant in terms of DPPH scavenging activity and ferric reducing antioxidant power, where the greater TPC of A. disticha resulted in higher antioxidant activities. This claim was in line with the study conducted by Maizura et al. (2011) who reported significant and linear relationship between phenolic content and DPPH assay $\left(r=0.86, \mathrm{R}^{2}=0.7328\right)$ and between TPC and FRAP assay $\left(r=0.91, R^{2}=0.8220\right)$ of Polygonum minus (kesum), Zingiber officinale (ginger) and Curcuma longa (turmeric) extracts.

The content of individual phenolic compound in A. disticha as evident from HPLC analysis presented in Fig. 1 showed that gallic acid was the most abundant phenolic compounds in all plant parts. The stem extract displayed the highest gallic acid content followed by root and leaf extracts with mean value of $319.69 \pm 6.69 \mu \mathrm{g} / \mathrm{g}$ extract, $212.12 \pm 1.44 \mu \mathrm{g} / \mathrm{g}$ extract and $80.47 \pm 0.80 \mu \mathrm{g} / \mathrm{g}$ extract, respectively. The presence of gallic acid was also identified in root bark of A. dichostyla (Khallouki et al. 2007). 
The content of $p$-coumaric acid was significantly different $(\mathrm{p}<0.05)$ among the plant parts with values of $39.75 \pm 1.25 \mu \mathrm{g} / \mathrm{g}$ extract, $33.27 \pm 0.98 \mu \mathrm{g} / \mathrm{g}$ extract and $30.23 \pm 0.61 \mu \mathrm{g} / \mathrm{g}$ extract for stem, root and leaf, respectively (Fig. 1). The study of Pawar and Dasgupta (2016) reported that $p$-coumaric acid is associated with its antioxidant capability with various physiological actions.

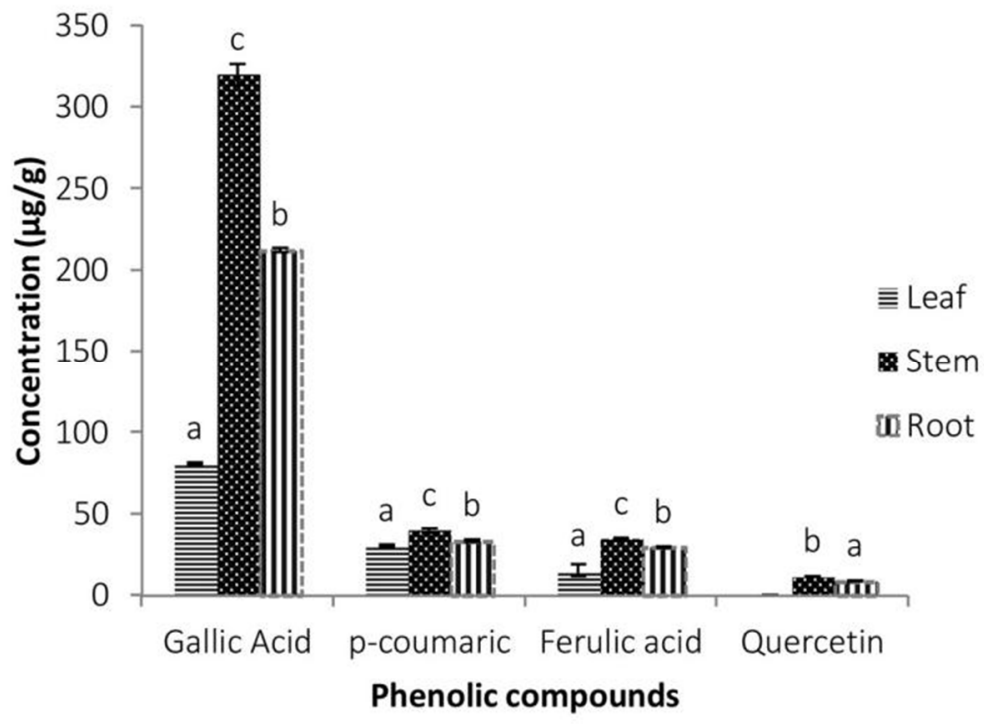

Fig. 1. Quantification of phenolic compounds in different parts of A. disticha. The values were expressed as mean \pm standard deviation $(n=3)$. Different letters indicate significant difference at the level of $\mathrm{p}<0.05$ between plant parts.

HPLC analysis of the plant under study revealed that the amount of ferulic acid present in $A$. disticha was $34.51 \pm 0.47 \mu \mathrm{g} / \mathrm{g}$ extract in stem, $29.20 \pm 0.51 \mu \mathrm{g} / \mathrm{g}$ extract in root and $15.08 \pm 3.61$ $\mu \mathrm{g} / \mathrm{g}$ extract in leaf (Fig. 1). Previous study has indicated that ferulic acid exert numerous health benefits particularly as antioxidant, antimicrobial and anticancer activities (Mussatto et al. 2007). In the present study, quercetin was found in the lowest concentration of $11.31 \pm 0.10 \mu \mathrm{g} / \mathrm{g}$ extract and $8.51 \pm 0.28 \mu \mathrm{g} / \mathrm{g}$ extract in stem and root, respectively and was not detected in leaf sample of A. disticha (Fig. 1). Quercetin has been reported to confer various health benefits including antioxidant, antiviral, anticancer, anti-inflammatory, cardiovascular properties as well as able to reduce mouth sores and asthma (Kumar et al. 2017).

From the present investigations it may be concluded that ethanolic extracts of $A$. disticha exhibited positive result for bacterial growth inhibitory activity for all plant parts, but their effectiveness was considered weak against Gram positive bacteria. Stem extract showed the highest TPC and potent free radical scavenging and reducing activities. The results also demonstrated significant positive correlation between TPC and antioxidant activities, suggesting that phenolic compounds contribute to oxidative properties of $A$. disticha. The presence of several phenolic compounds supports the traditional uses of this plant for different biological activities and suggests that $A$. disticha have potential as source of natural antimicrobial and antioxidants agents. 


\section{Acknowledgements}

This work was supported by IIUM Research Acculturation Grant Scheme (IRAGS) 18-0380039, International Islamic University Malaysia (IIUM), Malaysia.

\section{References}

Bauer AW, Kirby WM, Sheriss JC and Turc M 1966. Antibiotic susceptibility testing by standardized single method. Am. J. Clin. Pathol. 45:493-496.

Benzie IF and Strain JJ 1996. The ferric reducing ability of plasma (FRAP) as a measure of "antioxidant power": the FRAP assay. Anal. Biochem. 239(1): 70-76.

Chian LK 2019. The DNA of Singapore: Anisophyllea disticha Jack. Retrieved November 19, 2019. https://lkcnhm.nus.edu.sg/dna/organisms/details/354

Kaur GJ and Arora DS 2009. Antibacterial and phytochemical screening of Anethum graveolens, Foeniculum vulgare and Trachyspermum ammi. BMC Complement Altern Med. 9(1): 30.

Keller PA and Nugraha AS 2011. Revealing indigenous Indonesian traditional medicine: anti-infective agents. Nat. Prod. Commun. 6(12): 1953-1966.

Khallouki F, Haubner R, Hull WE, Erben G, Spiegelhalder B, Bartsch H and Owen RW 2007. Isolation, purification and identification of ellagic acid derivatives, catechins, and procyanidins from the root bark of Anisophyllea dichostyla R. Br. Food Chem. Toxicol. 45(3): 472-485.

Kumar R, Vijayalakshmi S and Nadanasabapathi S 2017. Health benefits of quercetin. Def. Life Sci. J. 2(2): $142-151$

Liu H, Qiu N, Ding H and Yao R 2008. Polyphenols contents and antioxidant capacity of 68 Chinese herbals suitable for medical or food uses. Food Res. Int. 41(4): 363-370.

Maizura M, Aminah A and Wan Aida WM 2011. Total phenolic content and antioxidant activity of kesum (Polygonum minus), ginger (Zingiber officinale) and turmeric (Curcuma longa) extract. Int. Food Res. J. 18(2): 529-534.

Mussatto SI, Dragone G and Roberto IC 2007. Ferulic and $p$-coumaric acids extraction by alkaline hydrolysis of brewer's spent grain. Ind. Crops Prod. 25(2): 231-237.

Ong HC 2004. Tumbuhan liar: khasiat ubatan \& kegunaan lain. Kuala Lumpur: Utusan Publications, 91.

Onivogui G, Letsididi R, Diaby M, Wang L and Song Y 2016. Influence of extraction solvents on antioxidant and antimicrobial activities of the pulp and seed of Anisophyllea laurina $\mathrm{R}$. Br. ex Sabine fruits. Asian Pac. J. Trop. Biomed. 6(1): 20-25.

Onivogui G, Zhang X, Diaby M, Maomy CG and Song Y 2017. Potential nutritional and antioxidant activity of various solvent extracts from leaves and stem bark of Anisophyllea laurina $\mathrm{R} . \mathrm{Br}$ ex Sabine used in folk medicine. Braz. J. Pharm. Sci. 53(2): 1-12.

Pawar SS and Dasgupta D 2016. Quantification of phenolic content from stem-bark and root of Hugonia mystax Linn. using RP-HPLC. J. King Saud Univ. Sci. 30: 293-300.

Prabuseenivasan S, Jayakumar M and Ignacimuthu S 2006. In vitro antibacterial activity of some plant essential oils. BMC Complement Altern Med. 6(1): 39.

Quattrocchi U 2012. CRC world dictionary of medicinal and poisonous plants: common names, scientific names, eponyms, synonyms, and etymology. Boca Raton: CRC Press, 308.

Siddhuraju P, Mohan PS and Becker K 2002. Studies on the antioxidant activity of Indian Laburnum (Cassia fistula L.): A preliminary assessment of crude extracts from stem bark, leaves, flowers and fruit pulp. Food Chem. 79(1): 61-67.

Singh A 2016. Compendia of world's medicinal flora. CRC Press, 67.

Suharjito D, Darusman LK, Darusman D and Suwarno E 2014. Comparing medicinal plants use for traditional and modern herbal medicine in Long Nah Village of East Kalimantan. Bionatura. 16(2): 95102.

Sulaiman S, Ibrahim D, Kassim J and Sheh-Hong L 2011. Antimicrobial and antioxidant activities of condensed tannin from Rhizophora apiculata barks. J. chem. pharm. 3(4): 436-444. 
Tasioula-Margari M and Tsabolatidou E 2015. Extraction, separation, and identification of phenolic compounds in virgin olive oil by HPLC-DAD and HPLC-MS. Antioxidants. 4(3): 548-562.

Yilmaz EI, Yavuz M and Kizil M 2008. Molecular characterization of rhizospheric soil streptomycetes isolated from indigenous Turkish plants and their antimicrobial activity. World J Microb Biot. 24(8): 1461-1470.

Zheng W and Wang SY 2001. Antioxidant activity and phenolic compounds in selected herbs. J. Agric. Food Chem. 49(11): 5165-5170.

(Manuscript received on 21 July, 2020; revised on 5 October, 2020) 